\title{
Genome-wide association study of chronic sputum production implicates loci involved in mucus production and infection
}

\author{
Packer $\mathrm{R}^{1}$, Shrine $\mathrm{N}^{1}$, Hall $\mathrm{R}^{2}$, Melbourne $\mathrm{C}^{1}$, Thompson $\mathrm{R}^{2}$, Williams $\mathrm{AT}^{1}$, Paynton $\mathrm{ML}^{1}$, Davitte $\mathrm{J}^{3}$, \\ Hessel $E^{4}$, Michalovich $D^{4}$, Betts $J C^{4}$, Sayers $I^{2}$, Yeo $A^{4}$, Hall IP2 , Tobin MD ${ }^{1,5}$, Wain $L^{1,5}$ \\ 1 Department of Health Sciences, University of Leicester, Leicester, UK. \\ 2 School of Medicine and NIHR Nottingham Biomedical Research Centre, University of Nottingham, \\ Nottingham, UK \\ 3. GSK R\&D, Collegeville, PA, USA \\ 4. GSK R\&D, Stevenage, UK \\ 5. Leicester NIHR Biomedical Research Centre, Glenfield Hospital, Leicester, UK \\ Corresponding Author: Louise V Wain louisewain@leicester.ac.uk
}

\section{Acknowledgements}

The research was partially supported by the NIHR Leicester Biomedical Research Centre and the NIHR Nottingham Biomedical Research Centre; the views expressed are those of the author(s) and not necessarily those of the NHS, the NIHR or the Department of Health. This research was funded in part by the Wellcome Trust. For the purpose of open access, the author has applied a CC BY public copyright licence to any Author Accepted Manuscript version arising from this submission. We acknowledge the support of the Health Data Research UK BREATHE Digital Innovation Hub (UKRI Award MC_PC_19004). This research was conducted under UK Biobank application 45243. This research used the SPECTRE and ALICE High Performance Computing Facility at the University of Leicester.

\section{Conflicts of interest}

L.V.W. holds a GSK/British Lung Foundation Chair in Respiratory Research (C17-1). M.D.T. is supported by a Wellcome Trust Investigator Award (WT202849/Z/16/Z). M.D.T. and I.P.H. hold NIHR Senior Investigator Awards. LVW, MDT, IS and IPH report collaborative research funding from GSK to undertake the submitted work. LVW, MDT and RP report funding from Orion Pharma outside of the submitted work. LVW reports consultancy for Galapagos. JD, EH, DM, JCB and AY were employees of GSK at the time of this study. DM is an employee of Benevolent Al. 
medRxiv preprint doi: https://doi.org/10.1101/2022.01.11.22269075; this version posted January 11, 2022. The copyright holder for this preprint (which was not certified by peer review) is the author/funder, who has granted medRxiv a license to display the preprint in perpetuity.

It is made available under a CC-BY 4.0 International license.

\section{Abstract}

\section{Background}

Chronic sputum production impacts on quality of life and is a feature of many respiratory diseases. Identification of the genetic variants associated with chronic sputum production in a disease agnostic sample could improve understanding of its causes and identify new molecular targets for treatment.

\section{Methods}

We conducted a genome-wide association study (GWAS) of chronic sputum production in UK Biobank. Signals meeting genome-wide significance $\left(P<5 \times 10^{-8}\right)$ were fine-mapped and putative causal genes identified by gene expression analysis. GWAS of respiratory traits were interrogated to identify whether the signals were driven by existing respiratory disease amongst the cases and variants were further investigated for wider pleiotropic effects using phenome-wide association studies (PheWAS).

\section{Findings}

From a GWAS of 9,714 cases and 48,471 controls, we identified six novel genome-wide significant signals for chronic sputum production including the Human Leukocyte Antigen (HLA) locus, chromosome 11 mucin locus (containing MUC2, MUC5AC and MUC5B) and the FUT2 locus. The mucin locus signal had previously been reported for association with moderate-to-severe asthma. The HLA signal was fine-mapped to an amino-acid change of threonine to arginine (frequency $36.8 \%$ ) in HLA-DRB1 (HLA-DRB1*03:147). The signal near FUT2 was associated with expression of several genes including FUT2, for which the direction of effect was tissue dependent. Our PheWAS identified a wide range of associations.

\section{Interpretation}

Novel signals at the FUT2 and mucin loci highlight mucin flucosylation as a driver of chronic sputum production even in the absence of diagnosed respiratory disease and provide genetic support for this pathway as a target for therapeutic intervention. 
medRxiv preprint doi: https://doi.org/10.1101/2022.01.11.22269075; this version posted January 11, 2022. The copyright holder for this preprint (which was not certified by peer review) is the author/funder, who has granted medRxiv a license to display the preprint in perpetuity.

It is made available under a CC-BY 4.0 International license.

\section{$\underline{\text { Introduction }}$}

Increased sputum production impacts on daily activities and quality of life [1-4] and is a shared feature of many respiratory diseases. Worldwide, 545 million people have chronic respiratory conditions, with those associated with chronic sputum production including chronic obstructive pulmonary disease (COPD), asthma, bronchiectasis, chronic bronchitis, and cystic fibrosis. Chronic respiratory disease is the third leading cause of death worldwide, with 3.91 million deaths in 2017 [5].

The determinants of chronic sputum production in disease are not completely understood [6]. Most studies of excess sputum production have been in subjects with chronic bronchitis and COPD where it has been associated with lower lung function $[7,8]$ and higher risk of both exacerbation and respiratory symptoms [9]. Risk factors for excess sputum production include smoking and occupational and environmental pollutants [8, 10-12]. Currently available drug treatments for those with chronic sputum production do not generally affect the rate of production of sputum, but act as mucolytics and expectorants [13-15].

Genome-wide association studies have highlighted pathways underlying a range of respiratory traits and diseases, and highlighted potentially relevant drug targets [16, 17]. Previous genome wide association studies of sputum production have been limited to cohorts of smokers $[18,19]$ or those with diagnosed COPD $[20,21]$ and have not identified any genome-wide significant findings.

We hypothesised that identifying genetic variants that are associated with chronic sputum production in a large general population sample could improve understanding of its causes and identify new molecular targets for treatment. To test this hypothesis, we undertook a genome-wide association study (GWAS) of risk of chronic sputum production in 9,714 cases and 48,471 controls from UK Biobank. We performed phenome-wide association studies (PheWAS) and interrogation of gene expression data to characterise the association signals and determine which genes may be driving these signals.

\section{Methods}

\section{Study population}

Information about chronic sputum production was obtained from the online lifetime occupation survey that was emailed to 324,653 UK Biobank participants with existing email addresses between June and September 2015 and achieved a response rate of 38\% (31\% of all of those contacted provided a full completion of the questionnaire [22]). For this study, we defined cases as those who answered "yes" to the question "do you bring up phlegm/sputum/mucus daily?" (UK Biobank field 22504 , total 121,283 participants provided a "yes" or "no" response). Controls were defined as those who answered "no" to this question. Cases and controls were further restricted to those of genetically-determined European ancestry, as previously defined [23], with available smoking data (field 20160). Related individuals were removed, with cases preserved over controls when excluding one of a pair (or more) of related individuals (field 22021, "related" defined as a KING kinship coefficient $\geq 0.0884$, equivalent to second-degree relatedness or closer). For related pairs within the cases or controls, the individual with the lowest genotype missingness (field 22005) was retained. 
medRxiv preprint doi: https://doi.org/10.1101/2022.01.11.22269075; this version posted January 11, 2022. The copyright holder for this preprint (which was not certified by peer review) is the author/funder, who has granted medRxiv a license to display the preprint in perpetuity.

It is made available under a CC-BY 4.0 International license .

From all available controls, we defined a subset of controls with a similar age (field id 34 ) and sex (field id 31) distribution to the cases at a 1:5 ratio with the cases.

Demographics and respiratory characteristics of the case and controls were derived using the following definitions: doctor-diagnosed asthma (UK Biobank field 22127), moderate-to-severe asthma (as previously described [24]), doctor-diagnosed chronic bronchitis (field 22129), cough on most days (field 22502), smoking status (field 20160), COPD Global Initiative for Chronic Obstructive Lung Disease (GOLD) stage 1-4 and stages 2-4 (defined using baseline spirometry as previously described [23], [25]) bronchiectasis and cystic fibrosis (Supplementary Tables 1 and 2).

The overlap of primary care sputum codes with the chronic sputum production question (UK Biobank field 22504) was evaluated to identify whether primary care codes could be used to define an additional independent case-control dataset from those in UK Biobank who did not respond to the online lifetime occupation survey (Supplementary text).

UK Biobank has ethical approval from North West - Haydock Research Ethics Committee (21/NW/0157).

Genome-wide association study of chronic sputum production

Genetic data from the v3 March 2018 UK Biobank data release, imputed to the Haplotype Reference Consortium panel r1.12016, was used for the genome-wide association study.

Association testing was performed using logistic regression under an additive genetic model in PLINK 2.0 [26] with age, sex, array version, never/ever smoking status and the first 10 principal components of ancestry as covariates. Variants were excluded if they had an imputation quality INFO score $<0.5$ or a minor allele count (MAC) $<20$. Association signals were considered genomewide significant at $\mathrm{P}<5 \times 10^{-8}$. Independent signals were initially defined using a $1 \mathrm{Mb}$ window $(500 \mathrm{~kb}$ each side of the sentinel variant) and then using conditional analyses implemented in GCTA-COJO [27]. All variant coordinates are for genome build GRCh37. Region plots were created using LocusZoom [28].

\section{Fine-mapping}

We undertook Bayesian fine-mapping (29) for all genome-wide significant signals that were not in the HLA region to define $99 \%$ credible sets of variants i.e. sets of variants that are $99 \%$ probable to contain the true causal variant (assuming that it has been measured).

For signals within the HLA region (chr6:29,607,078-33,267,103 (b37)), we re-imputed our discovery samples using IMPUTE2 v2.3.1 with a reference panel for 424 classical HLA alleles and 1,276 amino acid changes [29] and repeated the association testing as described above.

Mapping association signals to putative causal genes

We used functional annotation and co-localisation with expression Quantitative Trait Loci (eQTL) signals to identify putative causal genes at each signal.

Annotation of the variants in each credible set was performed using SIFT [30], PolyPhen-2 and CADD, all implemented using the Ensemble GRCh37 Variant Effect Predictor (VEP) [31], alongside FATHMM 
medRxiv preprint doi: https://doi.org/10.1101/2022.01.11.22269075; this version posted January 11, 2022. The copyright holder for this preprint (which was not certified by peer review) is the author/funder, who has granted medRxiv a license to display the preprint in perpetuity.

It is made available under a CC-BY 4.0 International license .

[32]. Variants were annotated as deleterious if they were labelled deleterious by SIFT, probably damaging or possibly damaging by PolyPhen-2, damaging by FATHMM (specifying the "Inherited Disease" option of the "Coding Variants" method, and using the "Unweighted" prediction algorithm) or had a CADD scaled score $\geq 20$.

We queried the sentinel variants in GTEx V8 [33] and BLUEPRINT [34] (see Supplementary Table 3 for list of tissues). We tested for colocalisation of GWAS and eQTL signals using coloc [35]; $\mathrm{H} 4>80 \%$ was used to define a shared causal variant for eQTL and GWAS signals.

\section{Associations with other phenotypes}

To investigate whether the signals of association with sputum production were driven by underlying respiratory phenotypes of the cases, a look-up for each signal was undertaken for twelve respiratory or respiratory-related traits from GWAS results (moderate-to-severe asthma ( $\mathrm{N}$ cases=5,135, controls $=25,675$ ) [24], lung function (Forced Expired Volume in 1 second [FEV 1 ], Forced Vital Capacity [FVC], $\mathrm{FEV}_{1} / \mathrm{FVC}$, peak expiratory flow $\left.(\mathrm{PEF})\right)(\mathrm{N}=400,102)[23]$, respiratory infection ( $\mathrm{N}$ cases $=19,459$, controls $=101,438$ ) [36], idiopathic pulmonary fibrosis (IPF) ( $N$ cases $=2,668$, controls $=8,591)$ [37], smoking traits (Smoking age-of-onset $(\mathrm{N}=124,590)$, smoking cessation ( $\mathrm{N}$ cases $=141,649$, controls=27321), smoking cigarettes-per-day $(\mathrm{N}=120,744)$, smoking initiation ( $\mathrm{N}$ cases $=170,772$, controls $=212,859)$ and asthma ( $N$ cases $=23,948$, controls $=118,538)$ [38]). Smoking trait results were from the UK Biobank component of [39]. Where the sentinel variant was not available in the look-up dataset, we utilised an alternative variant from the credible set with the highest posterior probability of being causal. A Bonferroni adjustment for 72 association tests was applied requiring a $\mathrm{P}<6.94 \times 10^{-4}$ for association to be classified as statistically significant. HLA gene allele or amino acid changes were used in lookups where HLA imputation had been performed (available in the lung function [23], IPF [37], respiratory infection [36] and moderate-to-severe asthma [24] GWAS).

To further investigate whether the effects of the variants associated with risk of chronic sputum production differ between ever and never smokers, or between individuals with and without a history of chronic respiratory disease (spirometry defined COPD GOLD1+, doctor diagnosed asthma or doctor diagnosed chronic bronchitis), we tested association of sentinel variants in ever and never smokers and those with and without evidence of chronic respiratory disease separately.

To investigate associations of the chronic sputum-associated variants with a wider range of phenotypes, we performed a phenome-wide association study (PheWAS) of 2172 traits in UK Biobank (FDR $<0.01$, Supplementary Text) and searched Open Targets Genetics Portal $\left(P<5 \times 10^{-8}\right.$, version 0.4.0 (bd664ca) - accessed $16^{\text {th }}$ April 2021 [40]).

\section{$\underline{\text { Results }}$}

A total of 10,481 participants answered "yes" to the question "Do you bring up phlegm/sputum/mucus daily?" and 110,802 answered "no" (Supplementary Table 4). A total of 9,714 cases and 48,471 controls (Table 1), and 27,317,434 variants, were included in the GWAS. Ever-smoking and respiratory disease were more common in the cases than in the controls. The genomic control inflation factor (lambda) was 1.026 so no adjustments to the test statistics were 
medRxiv preprint doi: https://doi.org/10.1101/2022.01.11.22269075; this version posted January $11,2022$. The copyright holder for this preprint (which was not certified by peer review) is the author/funder, who has granted medRxiv a license to display the preprint in perpetuity.

It is made available under a CC-BY 4.0 International license .

applied (Figure 1). Six independent novel signals met the genome-wide significance threshold of $\mathrm{P}<5 \times 10^{-8}$ (Figure 2 and Table 2, Supplementary Figures 1 to 6 ).

Table 1 Demographics, ever-smoking status, doctor-diagnosed asthma, doctor-diagnosed chronic bronchitis, cough, moderate-to-severe asthma and COPD GOLD stage 1-4 status of cases and controls included in the GWAS of chronic sputum production. ${ }^{*}$ Total 6942 cases and 36321 controls with available spirometry that passed QC.

\begin{tabular}{|l|c|c|}
\hline & $\begin{array}{c}\text { Cases } \\
\mathrm{N}=9714\end{array}$ & $\begin{array}{c}\text { Controls } \\
\mathrm{N}=48471\end{array}$ \\
\hline Mean age (years) & 57.7 & 57.7 \\
\hline \% female & 42.5 & 42.5 \\
\hline Ever smoked (\%) & $5306(\mathbf{5 4 . 6 )}$ & $20912(\mathbf{4 3 . 1})$ \\
\hline Doctor-diagnosed chronic bronchitis (\%) & $407(\mathbf{4 . 2})$ & $416(\mathbf{0 . 8 6})$ \\
\hline Doctor-diagnosed asthma (\%) & $2630(\mathbf{2 7 . 1 )}$ & $5251(\mathbf{1 0 . 8 )}$ \\
\hline Cough on most days (\%) & $7022(\mathbf{7 2 . 3 )}$ & $3999(\mathbf{8 . 3 )}$ \\
\hline Moderate-to-severe asthma (\%) & $520(\mathbf{5 . 4 )}$ & $521(\mathbf{1 . 1})$ \\
\hline $\begin{array}{l}\text { Meets spirometry criteria GOLD 1-4 } \\
\text { (\%) }\end{array}$ & $1511(\mathbf{2 1 . 8})^{*}$ & $4766(\mathbf{1 3 . 1})^{*}$ \\
\hline
\end{tabular}

No systematic difference was seen in effect sizes between never and ever smokers for the six sentinel variants (Supplementary Figure 7). We observed that the MUC2 locus signal showed a larger effect amongst those without a history of chronic respiratory disease (and was more similar to the overall results) than those with respiratory disease (Supplementary Figure 8 and Supplementary Table 5). Through comparison of survey responses and linked primary care data we showed that primary care codes were not adequate proxies for the survey responses (Supplementary Text). 
medRxiv preprint doi: https://doi.org/10.1101/2022.01.11.22269075; this version posted January 11, 2022. The copyright holder for this preprint (which was not certified by peer review) is the author/funder, who has granted medRxiv a license to display the preprint in perpetuity.

It is made available under a CC-BY 4.0 International license.

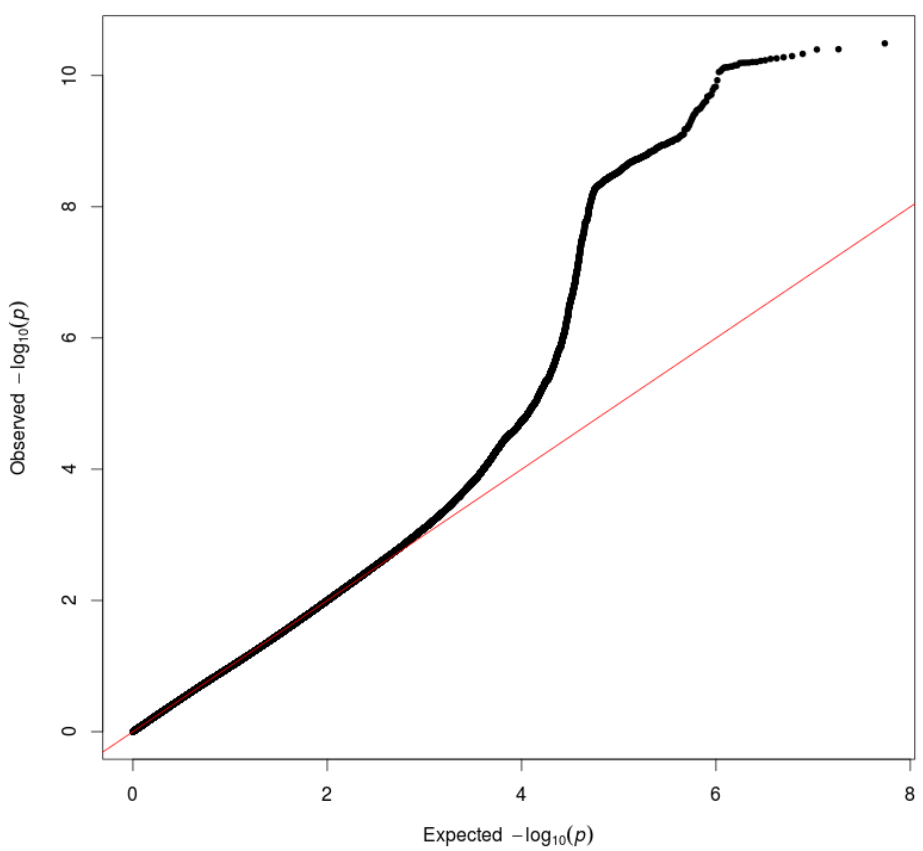

Figure 1 Quantile-quantile (QQ) plot for results of genome-wide association study of sputum production. Variants with imputation quality INFO $<0.5$ and minor allele count (MAC) $<20$ were excluded. The genomic control inflation factor, lambda, was 1.026.

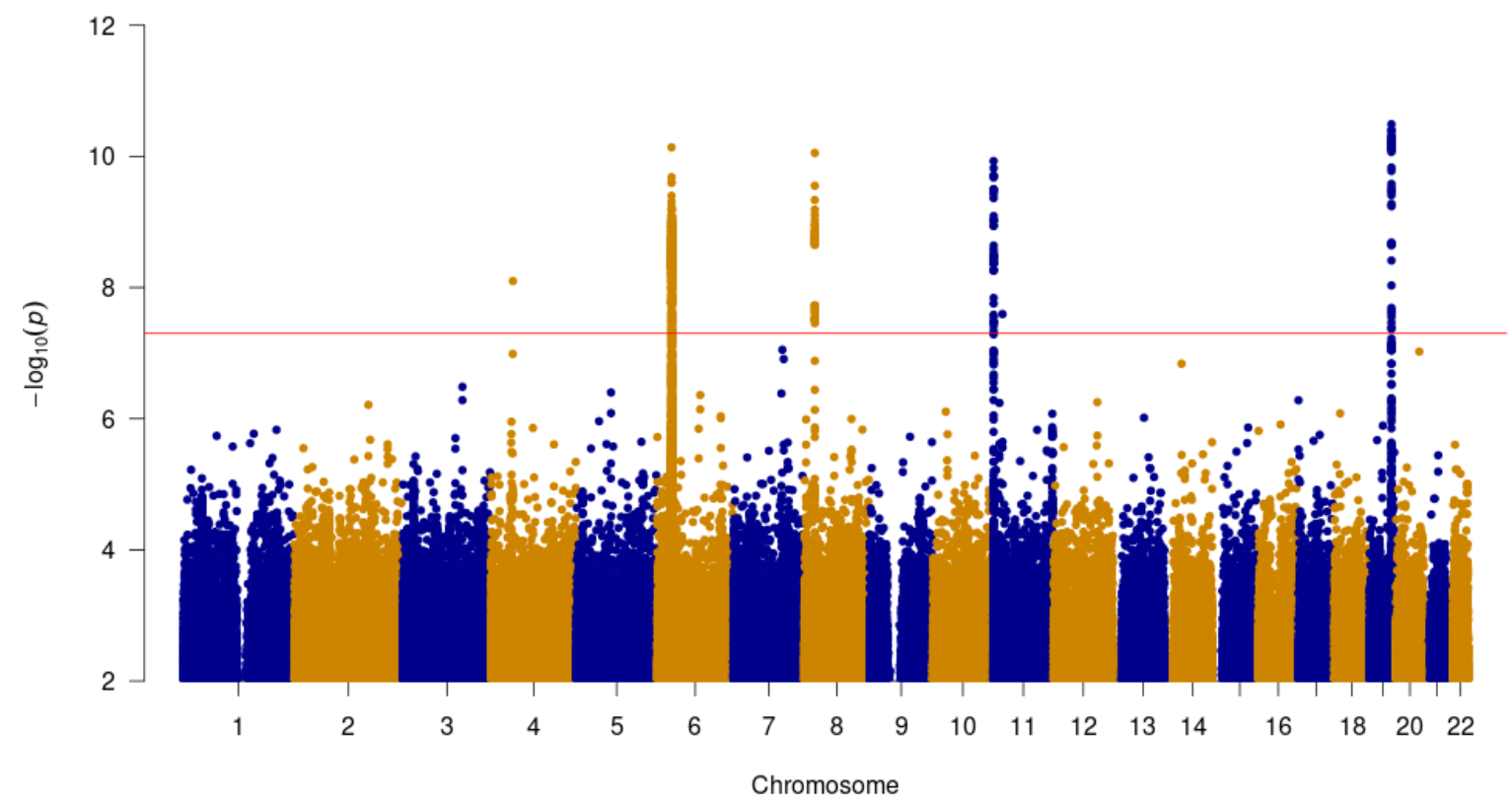

Figure 2 Manhattan plot for genome-wide association study of sputum production. The red line indicates genome-wide significance. 
Table 2: Novel genome-wide significant signals of association with sputum production.

\begin{tabular}{|c|c|c|c|c|c|c|c|c|}
\hline $\begin{array}{l}\text { Chr:Position } \\
\text { (GRCh37) }\end{array}$ & RSID & $\begin{array}{l}\text { Locus (BP distance } \\
\text { from gene)* }\end{array}$ & $\begin{array}{l}\text { coded/non- } \\
\text { coded }\end{array}$ & $\begin{array}{l}\text { Coded allele } \\
\text { frequency \% } \\
\text { (count) }\end{array}$ & OR (95 Cl) & $\mathbf{P}$ & $\begin{array}{l}\text { Imputation } \\
\text { quality (INFO) }\end{array}$ & $\begin{array}{l}\text { \# variants in } 99 \% \\
\text { credible set (highest } \\
\text { posterior } \\
\text { probability) }\end{array}$ \\
\hline 4:48854355 & rs79998532 & OCIAD1 (intronic) & $A / G$ & $0.2 \%(233)$ & $2.36(1.76-3.16)$ & $8.00 \times 10^{-09}$ & 0.92 & $3(0.86)$ \\
\hline $6: 32496534$ & rs374248993 & $H L A-D R B 1 \neq$ & $\mathrm{G} / \mathrm{C}$ & $57 \%(66355)$ & $1.12(1.08-1.16)$ & $7.30 \times 10^{-11}$ & 0.87 & $H L A-D R B 1^{*} 03: 147 \ddagger$ \\
\hline $8: 23480686$ & rs79401075 & $N K X 3-1(59,765)$ & $A / G$ & $10 \%(11620)$ & $1.18(1.12-1.24)$ & $8.90 \times 10^{-11}$ & 0.98 & $30(0.32)$ \\
\hline 11:1116931 & rs779167905 & $\operatorname{MUC2}(12,513)$ & T/TTCTA & $67 \%(78158)$ & $1.12(1.08-1.16)$ & $1.20 \times 10^{-10}$ & 0.98 & $30(0.15)$ \\
\hline $11: 20887601$ & rs529240826 & NELL1 (intronic) & $\mathrm{GC} / \mathrm{G}$ & $0.51 \%(588)$ & $1.91(1.52-2.4)$ & $2.50 \times 10^{-08}$ & 0.67 & $2(0.83)$ \\
\hline 19:49206417 & rs492602 & FUT2 (exonic) & $\mathrm{G} / \mathrm{A}$ & $51 \%(58803)$ & $1.11(1.08-1.15)$ & $3.20 \times 10^{-11}$ & 1 & $32(0.07)$ \\
\hline
\end{tabular}

$\neq=$ amino-acid change of threonine to arginine at codon 233 of exon 5 of HLA-DRB1 (HLA gene allele HLA-DRB1*03:147)

$\mathrm{BP}=$ base pairs $; \mathrm{OR}=$ odds ratio $\mathrm{Cl}=$ confidence interval

* Start or end of nearest gene 
medRxiv preprint doi: https://doi.org/10.1101/2022.01.11.22269075; this version posted January 11, 2022. The copyright holder for this preprint (which was not certified by peer review) is the author/funder, who has granted medRxiv a license to display the preprint in perpetuity.

It is made available under a CC-BY 4.0 International license.

\section{Novel associations with chronic sputum production}

HLA locus

The HLA signal was fine-mapped to an amino-acid change of threonine to arginine (frequency $36.8 \%$ ) at codon 233 of exon 5 of HLA-DRB1 (HLA-DRB1*03:147) that was associated with decreased risk (OR 0.91 [95\% C.I. 0.88-0.94]) of chronic sputum production $\left(P=3.43 \times 10^{-9}\right)$. The amino acid change was in linkage disequilibrium with the GWAS sentinel variant rs374248993 $\left(R^{2}=0.74\right)$ and the signal for rs374248993 was attenuated when conditioned on the amino acid change (Supplementary Figures 9 and 10).

HLA-DRB1*03:147 was significantly associated with $\mathrm{FEV}_{1}, \mathrm{FEV}_{1} / \mathrm{FVC}$ and PEF at genome-wide significance $\left(\mathrm{P}<5 \times 10^{-8}\right)$. The amino acid associated with increased risk of sputum production (threonine) was associated with increased lung function (Supplementary Table 6); this has not been previously reported.

\section{MUC2 locus}

The mucin locus signal (rs779167905) for risk of chronic sputum production on chromosome 11 was also significantly associated with asthma (OR 1.06, $\mathrm{P}=0.0027)$, moderate-to-severe asthma (OR 1.13, $\mathrm{P}=6.3 \times 10^{-7}$, FVC (beta $0.0087, \mathrm{P}=6 \times 10^{-4}$ ) and IPF (OR 0.84, $\left.\mathrm{P}=7.5 \times 10^{-6}\right)$ ). (Figure 3, Supplementary Table 6). There were no associations with any gene expression for $\mathrm{rs} 779167905$.

Genome-wide significant associations with IPF [41] and moderate-severe asthma [24] have previously been reported at this locus and so we undertook a conditional analysis to identify whether the sputum production signal was independent of these previous signals. Repeating the association testing for this variant conditioning on the previously reported variants (rs35705950 [41] and rs11603634 [24]) identified that the sputum GWAS signal was independent of the IPF signal ( $r$ 779167905, conditional $P=1.18 \times 10^{-10}$ ) but was not independent of the moderate-to-severe asthma signal (rs779167905, conditional $\mathrm{P}=0.0039$ ), see Supplementary Figures 11 and 12.

Our PheWAS and Open Targets Genetics Portal analysis identified that the MUC2 locus signal (rs779167905) allele that was associated with increased risk of chronic sputum production (allele A) was associated with higher risk of asthma and asthma-related traits [42-44] and lower risk of gallbladder disease (Supplementary Table 7 and 8).

FUT2 locus

The FUT2 credible set included two variants that were annotated as functional using VEP. This included a stop-gain variant in FUT2 (rs601338, r2 0.992 with sentinel rs492602) and a nearby missense variant (rs602662 r2 0.882 with sentinel rs492602) that resulted in a Glycine to Serine amino acid change for the allele positively correlated with the chronic sputum production risk allele (see Supplementary Table 9 and Supplementary Table 10).

Sentinel variant rs492602 at the FUT2 locus was associated with expression of FUT2, NTN5, RASIP1, SEC1P and MAMSTR for which there was support for co-localisation of eQTL and GWAS signals in multiple tissues from GTEx V8 (Figure 4, Supplementary Table 11). Increased risk of chronic sputum production was consistently correlated with increased expression of NTN5 and MAMSTR across a 
medRxiv preprint doi: https://doi.org/10.1101/2022.01.11.22269075; this version posted January 11, 2022. The copyright holder for this preprint (which was not certified by peer review) is the author/funder, who has granted medRxiv a license to display the preprint in

It is made available under a CC-BY 4.0 International license .

range of tissues. In contrast, the direction of the FUT2 expression signal varied by tissue with increased risk of chronic sputum production correlated with decreased expression of FUT2 in brain tissues and with increased expression in gastrointestinal tissue. There were no associations in lung tissue and upper airway tissues were not available.

The sentinel variant for the FUT2 region signal on chromosome 19 ( $r$ 492602) was associated with lung function measures $\mathrm{FEV}_{1} / \mathrm{FVC}$ and $\mathrm{PEF}\left(\mathrm{P}=2.2 \times 10^{-6}\right.$ and $\mathrm{P}=1.1 \times 10^{-6}$, respectively) with the chronic sputum production risk allele $(G)$ associated with decreased lung function (Figure 3, Supplementary Table 6).

Our PheWAS and Open Targets Genetics Portal analysis for this variant identified 141 associations spanning multiple disease areas, phenotypes and biomarkers (Supplementary Tables 7 and 8). In summary, the allele associated with increased risk of chronic sputum production was associated with increased risk of gallstones [43, 45, 46], type 1 diabetes [47] and Crohn's disease [48-51], elevated vitamin B12 [52-55] and cholesterol and fat metabolites [42, 43, 56-60], hypertension/cardiovascular disease $[43,45,61]$, excess alcohol with associated sequelae $[45,62-$ 64], increased risk of mumps and lower risk of childhood ear infections [65]. Higher risk of chronic sputum production was also associated with higher levels of gamma glutamyl transferase, total bilirubin and aspartate amino transferase, and lower levels of alanine aminotransferase and alkaline phosphatase.

\section{Other novel loci}

Using functional annotation of variants and eQTL analysis, no putative causal genes could be assigned to the signals in or near OCIAD1 and NELL1. There was a single co-localising eQTL for SLC25A37 in the NKX3-1 locus with increased risk of chronic sputum production associated with a reduced expression of SLC25A37 in brain cortex (Supplementary Table 11, Supplementary Figure 13). 


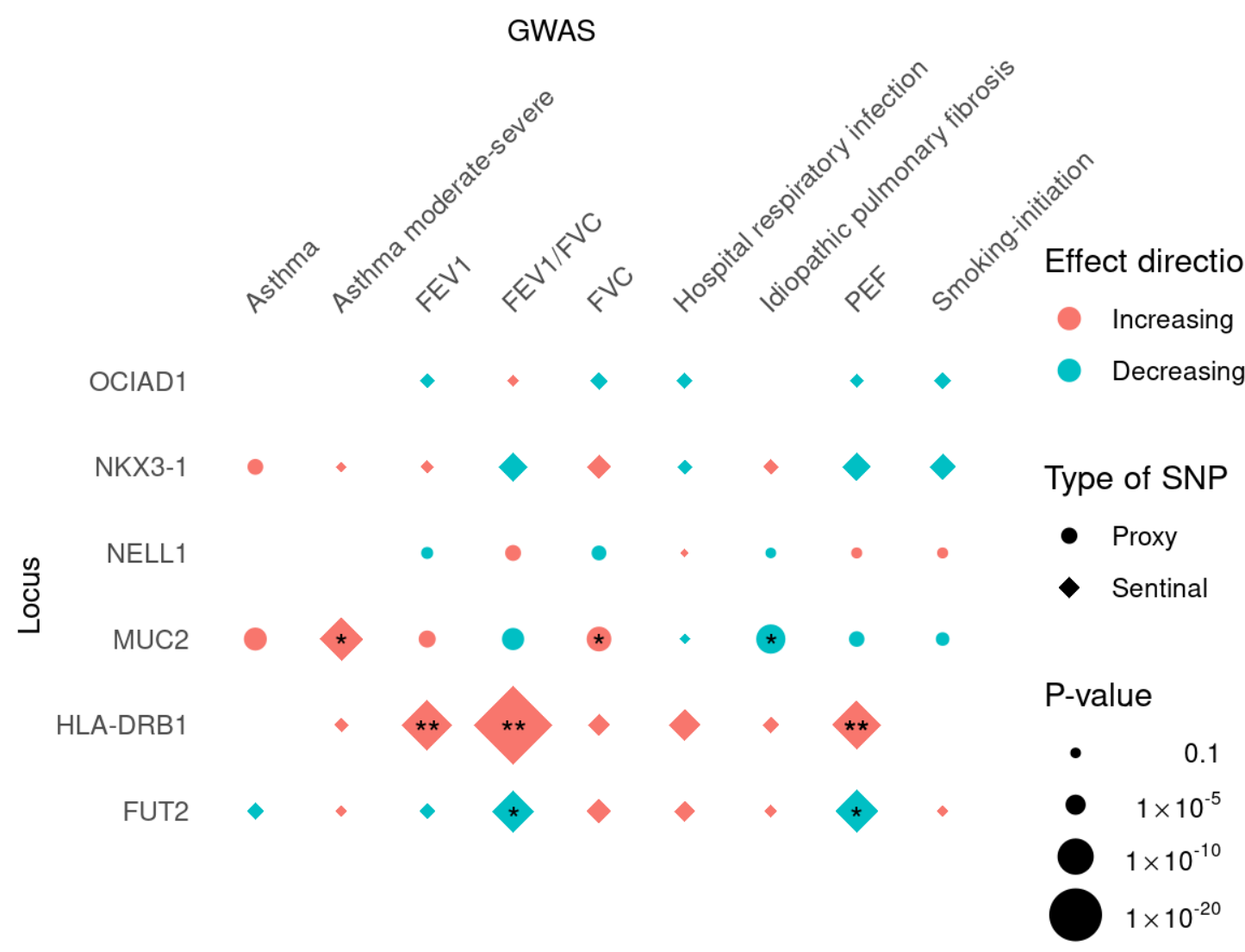

Figure 3 Results for association of sentinel variant risk alleles with respiratory traits. Results are aligned to the risk allele for chronic sputum production, effect direction 'Increasing' can be read as increasing risk for binary traits and increasing values in quantitative traits. Smoking age of onset, cigarettes per day and cessation phenotype lookups were omitted as no associations with $\mathrm{P}<0.05$ found. ${ }^{*} \mathrm{P}<6.94 \times 10^{-4}$ (Bonferroni adjustment for 72 association tests) $* * \mathrm{P}<5 \times 10^{-8}$. 


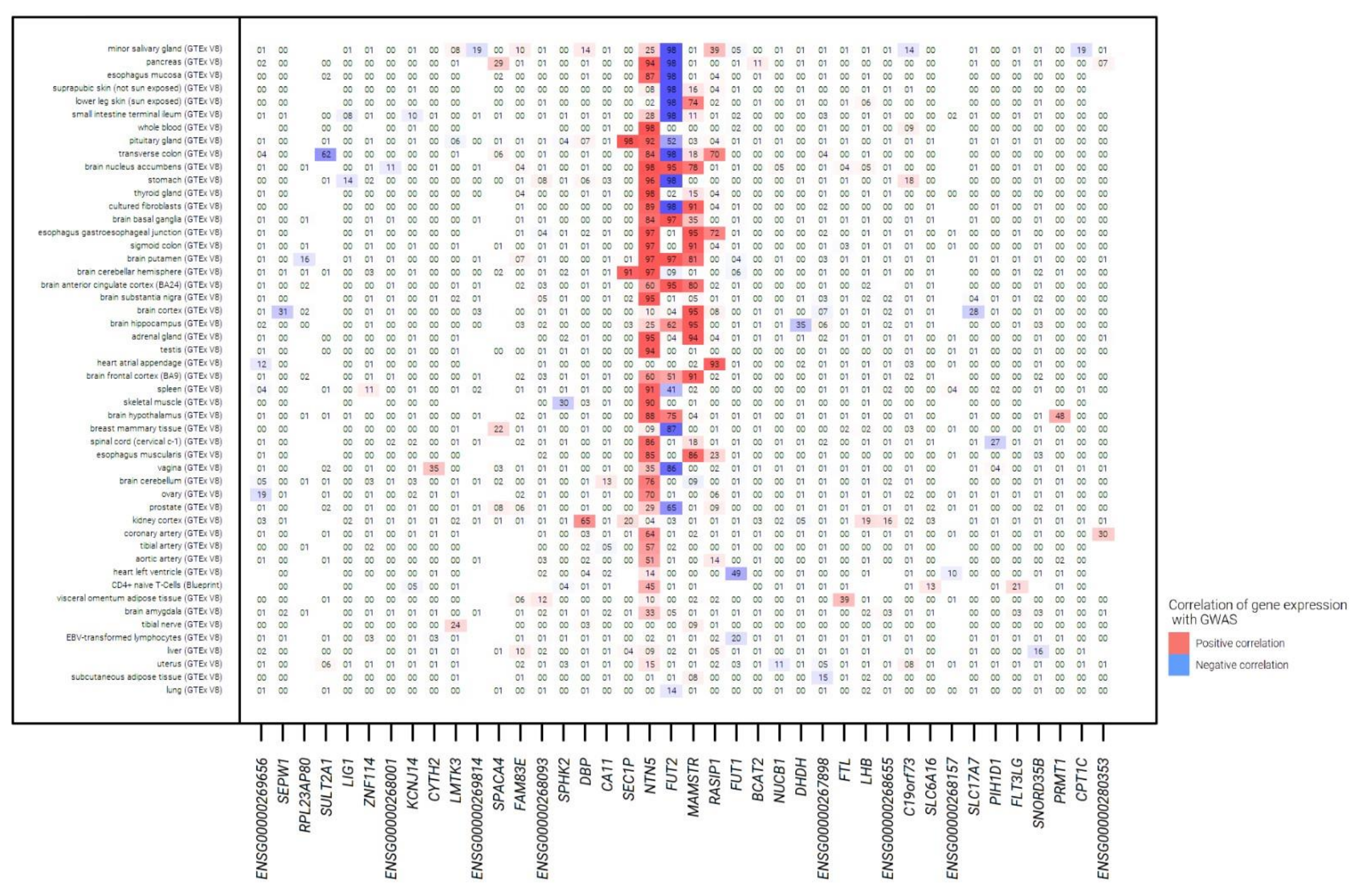

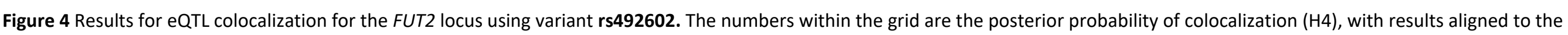
risk allele $\mathrm{G}$ for the rs492602 variant. Missing numbers indicate no data was available for the respective gene and tissue. 
medRxiv preprint doi: https://doi.org/10.1101/2022.01.11.22269075; this version posted January 11, 2022. The copyright holder for this preprint (which was not certified by peer review) is the author/funder, who has granted medRxiv a license to display the preprint in

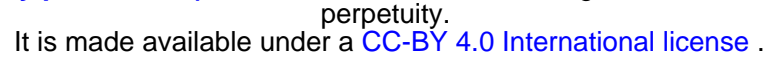

\section{Discussion}

We describe the first GWAS of chronic sputum production to identify genome-wide significant signals and our findings implicate genes involved in mucin production and fucosylation, as well as the HLA class II histocompatibility antigen, HLA-DRB1.

The most significant signal implicated the gene FUT2 which has been widely studied for its role in blood group antigen expression and association with gastric and respiratory infection. FUT2 encodes fucosyltransferase 2 which mediates the transfer of fucose to the terminal galactose on glycan chains of cell surface glycoproteins and glycolipids. FUT2 creates a soluble precursor oligosaccharide FuC-alpha $((1,2)$ Galbeta-) called the $\mathrm{H}$ antigen which is an essential substrate for the final step in the soluble ABO blood group antigen synthesis pathway. The FUT2 locus allele associated with increased risk of chronic sputum production in this study is correlated with a nonsense allele that leads to inactivated FUT2, which results in a non-secretory phenotype of $A B O(H)$ blood group antigens [66] for homozygous carriers. This nonsense allele ( $r 5601338$ allele A) has frequencies of $25-50 \%$ in South Asian, European and African populations but is rare $(<1 \%)$ in East Asian populations [67]. Candidate gene studies of this locus have identified that non-secretors (who are associated with high risk of chronic sputum production according to our study) have a lower risk of $\mathrm{H}$. Pylori infection [68], rotavirus A infection [69, 70], norovirus infection [71-73], infant (12-24 months) respiratory illness [74], asthma exacerbations [75], otitis media [76], exacerbation in non-cystic fibrosis bronchiectasis and Pseudomonas aeruginosa airway infection in the same group [77], some evidence of slower HIV progression [73] and a higher risk of pneumococcal and meningococcal infection [78]. The T allele of another variant in high linkage disequilibrium at this locus ( $r$ 681343, $r^{2}=0.996$ with $r s 492602$ ), associated with increased risk of chronic sputum production in our study, was recently reported to be associated with increased risk of human polyomavirus 1 (BKV) virus infection, as measured by antibody response [79]. A recent GWAS of critically ill cases of COVID-19 (cases N=7491), showed that the risk allele for chronic phlegm production $(G)$ of $r s 492602$ was protective against life threating COVID-19 ( $\left.P=4.55 \times 10^{-9}, \mathrm{OR} 0.88, \mathrm{Cl} 0.87-0.90\right)$ [80]. However, this finding was not replicated in the latest COVID-19 Host Genetics Initiative results for a similar phenotype [81].

Epitopes that are fucosylated by FUT2 play a role in cell-cell interaction including host-microbe interaction $[82,83]$ and mediate interaction with intestinal microbiota, thereby influencing its composition [84-87]. Whilst there has been no direct evidence of host-pathogen binding on the FUT2 generated epitopes for non-gastrointestinal infection there is evidence that FUT2 can influence non-binding ligands such as sialic acid [88]. Sialic acid binding has been shown to be important for adenovirus binding in cell models [89] and modulating this binding has been implicated as a possible mechanism for increasing risk of mumps infection [65].

FUT2 may also be key to the function of mucins, including those encoded by genes at our other significant locus (i.e. MUC2, MUC5AC, MUC5B). Analysis of oligosaccharides released from insoluble colonic mucins, largely Muc2, by mass spectrometry shows complete lack of terminal fucosylation of $O$-linked oligosaccharides in Fut2-LacZ-null mice [90]. FUT2 has also been shown to determine the $O$ glycosylation pattern of Muc5ac in mice [91]. The significant signal at MUC2 in our analysis was not independent of the previously reported moderate-to-severe asthma signal [24] for which MUC5AC was implicated as the most likely causal gene using gene expression data from bronchial epithelial 
medRxiv preprint doi: https://doi.org/10.1101/2022.01.11.22269075; this version posted January 11, 2022. The copyright holder for this preprint (which was not certified by peer review) is the author/funder, who has granted medRxiv a license to display the preprint in perpetuity.

It is made available under a CC-BY 4.0 International license.

cells. Although our analysis did not identify an association at the MUC2 locus with COPD-related traits ( $\mathrm{FEV}_{1}$ and $F E V_{1} / \mathrm{FVC}$ ), a recent study has also highlighted MUC5AC as a potential biomarker for COPD prognosis [92].

Our study demonstrates the value in studying a disease-relevant phenotype in a population that is unascertained with respect to inclusion (or exclusion) of respiratory disease or smoking status. We only report overlap of chronic sputum production association signals with association signals for gene expression regulation where there is statistical support that these signals share a causal variant. In addition to a comprehensive PheWAS, we provide a deeper assessment of associations with relevant respiratory phenotypes that highlights previously unreported associations with lung function for the HLA-DRB1 and FUT2 signals.

As only a subset of UK Biobank participants provided answers to the sputum production question, we expected that we might be able to define a replication case control dataset from the remaining $>300,000$ participants using primary care data. However, evaluation of the positive predictive value of primary care codes for sputum production, when compared to the questionnaire data, was very low (see Supplementary Text). This could reflect a low utilisation of sputum codes in primary care or that participants have not reported this symptom to their General Practitioner (GP). However, given the strong evidence summarised above for the involvement of the probable causal genes in control of pathways relevant to mucus production, we believe the associations identified are highly likely to be real.

In summary, the HLA, MUC2 and FUT2 loci show strong candidacy for a role in sputum production, with overlap with infection and related phenotypes and known mechanistic interactions between the genes at the FUT2 and MUC2 loci, suggesting that these signals are likely to be robust. The large number of associations of the FUT2 locus with a broad array of phenotypes, tissue-dependent expression of FUT2, and association with expression of other genes in the region, may have implications for drug targeting guided by this locus. Experimental studies to characterise the specific interplay between FUT2 activity and mucin genes expressed in the airways are warranted.

\section{Conclusion}

Chronic sputum production is a phenotype characteristic of several respiratory diseases, as well as being common cause for referrals in the absence of overt disease, and is of interest for pharmaceutical intervention. We report novel genetic factors which influence chronic sputum production and these signals highlight fucosylation of mucin as a driving factor of chronic sputum production. These signals could provide insight into the molecular pathways of sputum production and represent potential future targets for drug development [93].

\section{Data availability}

Genome-wide association statistics from the case-control analysis of chronic sputum production will be made available via GWAS Catalog [to be submitted following peer-review]. 
medRxiv preprint doi: https://doi.org/10.1101/2022.01.11.22269075; this version posted January 11, 2022. The copyright holder for this preprint (which was not certified by peer review) is the author/funder, who has granted medRxiv a license to display the preprint in perpetuity.

It is made available under a CC-BY 4.0 International license.

\section{$\underline{\text { References }}$}

1. Miravitlles $M$, Anzueto A, Legnani D, Forstmeier L, Fargel M. Patient's perception of exacerbations of COPD-the PERCEIVE study. Respiratory Medicine 2007; 101: 453-460.

2. Martínez-Rivera C, Crespo A, Pinedo-Sierra C, García-Rivero JL, Pallarés-Sanmartín A, MarinaMalanda N, Pascual-Erquicia S, Padilla A, Mayoralas-Alises S, Plaza V, López-Viña A, Picado C. Mucus hypersecretion in asthma is associated with rhinosinusitis, polyps and exacerbations. Respiratory Medicine 2018; 135: 22-28.

3. Barker AF. Bronchiectasis. N Engl J Med 2002; 346: 1383-1393.

4. Norrish C, Norrish M, Fass U, Al-Salmani M, Lingam GS, Clark F, Kallesh H. The Cystic Fibrosis Symptom Progression Survey (CF-SPS) in Arabic: A tool for monitoring patients' symptoms. Oman Med J 2015; 30: 16-25.

5. Li X, Cao X, Guo M, Xie M, Liu X. Trends and risk factors of mortality and disability adjusted life years for chronic respiratory diseases from 1990 to 2017: systematic analysis for the Global Burden of Disease Study 2017. BMJ 2020; : m234.

6. Kim V, Criner GJ. Chronic Bronchitis and Chronic Obstructive Pulmonary Disease. Am J Respir Crit Care Med 2013; 187: 228-237.

7. Kim V, Zhao H, Boriek AM, Anzueto A, Soler X, Bhatt SP, Rennard SI, Wise R, Comellas A, Ramsdell JW, Kinney GL, Han MK, Martinez CH, Yen A, Black-Shinn J, Porszasz J, Criner GJ, Hanania NA, Sharafkhaneh A, Crapo JD, Make BJ, Silverman EK, Curtis JL, COPDGene Investigators. Persistent and Newly Developed Chronic Bronchitis Are Associated with Worse Outcomes in Chronic Obstructive Pulmonary Disease. Ann Am Thorac Soc 2016; 13: 10161025.

8. Pelkonen $\mathrm{M}$, Notkola I-L, Nissinen A, Tukiainen $\mathrm{H}$, Koskela $\mathrm{H}$. Thirty-year cumulative incidence of chronic bronchitis and COPD in relation to 30-year pulmonary function and 40-year mortality: a follow-up in middle-aged rural men. Chest 2006; 130: 1129-1137.

9. Kim V, Han MK, Vance GB, Make BJ, Newell JD, Hokanson JE, Hersh CP, Stinson D, Silverman EK, Criner GJ, COPDGene Investigators. The chronic bronchitic phenotype of COPD: an analysis of the COPDGene Study. Chest 2011; 140: 626-633.

10. Dijkstra AE, de Jong K, Boezen HM, Kromhout $H$, Vermeulen R, Groen HJM, Postma DS, Vonk JM. Risk factors for chronic mucus hypersecretion in individuals with and without COPD: influence of smoking and job exposure on CMH. Occup Environ Med 2014; 71: 346-352.

11. Trupin L, Earnest G, San Pedro M, Balmes JR, Eisner MD, Yelin E, Katz PP, Blanc PD. The occupational burden of chronic obstructive pulmonary disease. Eur Respir J 2003; 22: 462-469.

12. Matheson MC, Benke G, Raven J, Sim MR, Kromhout $H$, Vermeulen R, Johns DP, Walters EH, Abramson MJ. Biological dust exposure in the workplace is a risk factor for chronic obstructive pulmonary disease. Thorax 2005; 60: 645-651.

13. Tarrant BJ, Le Maitre C, Romero L, Steward R, Button BM, Thompson BR, Holland AE. Mucoactive agents for chronic, non-cystic fibrosis lung disease: A systematic review and metaanalysis: Mucoactive agents in chronic non-CF management. Respirology 2017; 22: 1084-1092. 
medRxiv preprint doi: https://doi.org/10.1101/2022.01.11.22269075; this version posted January 11, 2022. The copyright holder for this preprint (which was not certified by peer review) is the author/funder, who has granted medRxiv a license to display the preprint in perpetuity.

It is made available under a CC-BY 4.0 International license.

14. Rubin BK. Mucolytics, expectorants, and mucokinetic medications. Respir Care 2007; 52: 859865.

15. Shen Y, Huang S, Kang J, Lin J, Lai K, Sun Y, Xiao W, Yang L, Yao W, Cai S, Huang K, Wen F. Management of airway mucus hypersecretion in chronic airway inflammatory disease: Chinese expert consensus (English edition). Int J Chron Obstruct Pulmon Dis 2018; 13: 399-407.

16. Wain LV, Shrine N, Artigas MS, Erzurumluoglu AM, Noyvert B, Bossini-Castillo L, Obeidat M, Henry AP, Portelli MA, Hall RJ, Billington CK, Rimington TL, Fenech AG, John C, Blake T, Jackson VE, Allen RJ, Prins BP, Understanding Society Scientific Group, Campbell A, Porteous DJ, Jarvelin M-R, Wielscher M, James AL, Hui J, Wareham NJ, Zhao JH, Wilson JF, Joshi PK, Stubbe B, et al. Genome-wide association analyses for lung function and chronic obstructive pulmonary disease identify new loci and potential druggable targets. Nat Genet 2017; 49: 416-425.

17. El-Husseini ZW, Gosens R, Dekker F, Koppelman GH. The genetics of asthma and the promise of genomics-guided drug target discovery. Lancet Respir Med 2020; 8: 1045-1056.

18. Dijkstra AE, Boezen HM, van den Berge $M$, Vonk JM, Hiemstra PS, Barr RG, Burkart KM, Manichaikul A, Pottinger TD, Silverman EK, Cho MH, Crapo JD, Beaty TH, Bakke P, Gulsvik A, Lomas DA, Bossé Y, Nickle DC, Paré PD, de Koning HJ, Lammers J-W, Zanen P, Smolonska J, Wijmenga C, Brandsma C-A, Groen HJM, Postma DS, the LifeLines Cohort Study group. Dissecting the genetics of chronic mucus hypersecretion in smokers with and without COPD. Eur Respir J 2015; 45: 60-75.

19. Dijkstra AE, Smolonska J, van den Berge M, Wijmenga C, Zanen P, Luinge MA, Platteel M, Lammers J-W, Dahlback M, Tosh K, Hiemstra PS, Sterk PJ, Spira A, Vestbo J, Nordestgaard BG, Benn M, Nielsen SF, DahI M, Verschuren WM, Picavet HSJ, Smit HA, Owsijewitsch M, Kauczor $\mathrm{HU}$, de Koning HJ, Nizankowska-Mogilnicka E, Mejza F, Nastalek P, van Diemen CC, Cho MH, Silverman EK, et al. Susceptibility to Chronic Mucus Hypersecretion, a Genome Wide Association Study. Hartl D, editor. PLoS ONE 2014; 9: e91621.

20. Zeng X, Vonk JM, de Jong $\mathrm{K}, \mathrm{Xu} X$, Huo X, Boezen HM. No convincing association between genetic markers and respiratory symptoms: results of a GWA study. Respir Res 2017; 18: 11.

21. Lee JH, Cho MH, Hersh CP, McDonald M-LN, Crapo JD, Bakke PS, Gulsvik A, Comellas AP, Wendt $\mathrm{CH}$, Lomas DA, Kim V, Silverman EK, COPDGene and ECLIPSE Investigators. Genetic susceptibility for chronic bronchitis in chronic obstructive pulmonary disease. Respir Res 2014; 15: 113.

22. De Matteis S, Jarvis D, Young H, Young A, Allen N, Potts J, Darnton A, Rushton L, Cullinan P. Occupational self-coding and automatic recording (OSCAR): a novel web-based tool to collect and code lifetime job histories in large population-based studies. Scand J Work Environ Health 2017; 43: 181-186.

23. Shrine N, Guyatt AL, Erzurumluoglu AM, Jackson VE, Hobbs BD, Melbourne CA, Batini C, Fawcett KA, Song K, Sakornsakolpat P, Li X, Boxall R, Reeve NF, Obeidat M, Zhao JH, Wielscher M, Weiss S, Kentistou KA, Cook JP, Sun BB, Zhou J, Hui J, Karrasch S, Imboden M, Harris SE, Marten J, Enroth S, Kerr SM, Surakka I, Vitart V, et al. New genetic signals for lung function highlight pathways and chronic obstructive pulmonary disease associations across multiple ancestries. Nat Genet 2019; 51: 481-493.

24. Shrine N, Portelli MA, John C, Soler Artigas M, Bennett N, Hall R, Lewis J, Henry AP, Billington CK, Ahmad A, Packer RJ, Shaw D, Pogson ZEK, Fogarty A, McKeever TM, Singapuri A, Heaney 
medRxiv preprint doi: https://doi.org/10.1101/2022.01.11.22269075; this version posted January 11, 2022. The copyright holder for this preprint (which was not certified by peer review) is the author/funder, who has granted medRxiv a license to display the preprint in perpetuity.

It is made available under a CC-BY 4.0 International license .

LG, Mansur AH, Chaudhuri R, Thomson NC, Holloway JW, Lockett GA, Howarth PH, Djukanovic R, Hankinson J, Niven R, Simpson A, Chung KF, Sterk PJ, Blakey JD, et al. Moderate-to-severe asthma in individuals of European ancestry: a genome-wide association study. The Lancet Respiratory Medicine 2019; 7: 20-34.

25. Global Initiative for Chronic Obstructive Lung Disease (GOLD), pocket guide to COPD diagnosis, management, and prevention. A Guide for health care professionals. [Internet]. 2019Available from: https://goldcopd.org/wp-content/uploads/2018/11/GOLD-2019-POCKET-GUIDEFINAL_WMS.pdf.

26. Purcell, Shaun C Christopher. Plink 2.0 [Internet]. Available from: www.coggenomics.org/plink/2.0/.

27. Yang J, Lee SH, Goddard ME, Visscher PM. GCTA: A Tool for Genome-wide Complex Trait Analysis. The American Journal of Human Genetics 2011; 88: 76-82.

28. Pruim RJ, Welch RP, Sanna S, Teslovich TM, Chines PS, Gliedt TP, Boehnke M, Abecasis GR, Willer CJ. LocusZoom: regional visualization of genome-wide association scan results. Bioinformatics 2010; 26: 2336-2337.

29. Jia X, Han B, Onengut-Gumuscu S, Chen W-M, Concannon PJ, Rich SS, Raychaudhuri S, de Bakker PIW. Imputing amino acid polymorphisms in human leukocyte antigens. PLOS ONE 2013; 8: e64683.

30. Sim N-L, Kumar P, Hu J, Henikoff S, Schneider G, Ng PC. SIFT web server: predicting effects of amino acid substitutions on proteins. Nucleic Acids Research 2012; 40: W452-W457.

31. McLaren W, Gil L, Hunt SE, Riat HS, Ritchie GRS, Thormann A, Flicek P, Cunningham F. The Ensembl Variant Effect Predictor. Genome Biol 2016; 17: 122.

32. Shihab HA, Gough J, Cooper DN, Stenson PD, Barker GLA, Edwards KJ, Day INM, Gaunt TR. Predicting the functional, molecular, and phenotypic consequences of amino acid substitutions using hidden Markov models. Hum. Mutat. 2013; 34: 57-65.

33. GTEx Consortium. Genetic effects on gene expression across human tissues. Nature 2017; 550: 204-213.

34. Chen L, Ge B, Casale FP, Vasquez L, Kwan T, Garrido-Martín D, Watt S, Yan Y, Kundu K, Ecker S, Datta A, Richardson D, Burden F, Mead D, Mann AL, Fernandez JM, Rowlston S, Wilder SP, Farrow S, Shao X, Lambourne JJ, Redensek A, Albers CA, Amstislavskiy V, Ashford S, Berentsen K, Bomba L, Bourque G, Bujold D, Busche S, et al. Genetic Drivers of Epigenetic and Transcriptional Variation in Human Immune Cells. Cell 2016; 167: 1398-1414.e24.

35. Giambartolomei C, Vukcevic D, Schadt EE, Franke L, Hingorani AD, Wallace C, Plagnol V. Bayesian Test for Colocalisation between Pairs of Genetic Association Studies Using Summary Statistics. Williams SM, editor. PLoS Genet 2014; 10: e1004383.

36. Williams AT, Shrine N, Naghra-van Gijzel H, Betts JC, Hessel EM, John C, Packer R, Reeve NF, Yeo AJ, Abner E, Åsvold BO, Auvinen J, Bartz TM, Bradford Y, Brumpton B, Campbell A, Cho MH, Chu S, Crosslin DR, Feng Q, Esko T, Gharib SA, Hayward C, Hebbring S, Hveem K, Jarvelin M-R, Jarvik GP, Landis SH, Larson EB, Liu J, et al. Genome-wide association study of susceptibility to hospitalised respiratory infections. Wellcome Open Res 2021; 6: 290. 
medRxiv preprint doi: https://doi.org/10.1101/2022.01.11.22269075; this version posted January 11, 2022. The copyright holder for this preprint (which was not certified by peer review) is the author/funder, who has granted medRxiv a license to display the preprint in perpetuity.

It is made available under a CC-BY 4.0 International license.

37. Allen RJ, Guillen-Guio B, Oldham JM, Ma S-F, Dressen A, Paynton ML, Kraven LM, Obeidat M, Li X, Ng M, Braybrooke R, Molina-Molina M, Hobbs BD, Putman RK, Sakornsakolpat P, Booth HL, Fahy WA, Hart SP, Hill MR, Hirani N, Hubbard RB, McAnulty RJ, Millar AB, Navaratnam V, Oballa E, Parfrey H, Saini G, Whyte MKB, Zhang Y, Kaminski N, et al. Genome-Wide Association Study of Susceptibility to Idiopathic Pulmonary Fibrosis. Am J Respir Crit Care Med 2019; : rccm.201905-10170C.

38. Demenais F, Bisgaard H, Barnes KC, Cookson WOC, Altmüller J, Ang W, Barr RG, Beaty TH, Becker AB, Beilby J, Bisgaard H, Bjornsdottir US, Bleecker E, Bønnelykke K, Boomsma DI, Bouzigon E, Brightling CE, Brossard M, Brusselle GG, Burchard E, Burkart KM, Bush A, ChanYeung M, Chung KF, Couto Alves A, Curtin JA, Custovic A, Daley D, de Jongste JC, Del-RioNavarro $B E$, et al. Multiancestry association study identifies new asthma risk loci that colocalize with immune-cell enhancer marks. Nat Genet 2018; 50: 42-53.

39. Jiang Y, Li Y, Brazel DM, Chen F, Datta G, Davila-Velderrain J, McGuire D, Tian C, Zhan X, Choquet $H$, Docherty AR, Faul JD, Foerster JR, Fritsche LG, Gabrielsen ME, Gordon SD, Haessler J, Hottenga J-J, Huang H, Jang S-K, Jansen PR, Ling Y, Mägi R, Matoba N, McMahon G, Mulas A, Orrù V, Palviainen T, Pandit $A$, Reginsson GW, et al. Association studies of up to 1.2 million individuals yield new insights into the genetic etiology of tobacco and alcohol use. Nat Genet 2019; 51: 237-244.

40. Carvalho-Silva D, Pierleoni A, Pignatelli M, Ong C, Fumis L, Karamanis N, Carmona M, Faulconbridge A, Hercules A, McAuley E, Miranda A, Peat G, Spitzer M, Barrett J, Hulcoop DG, Papa E, Koscielny G, Dunham I. Open Targets Platform: new developments and updates two years on. Nucleic Acids Research 2019; 47: D1056-D1065.

41. Seibold MA, Wise AL, Speer MC, Steele MP, Brown KK, Loyd JE, Fingerlin TE, Zhang W, Gudmundsson G, Groshong SD, Evans CM, Garantziotis S, Adler KB, Dickey BF, du Bois RM, Yang IV, Herron A, Kervitsky D, Talbert JL, Markin C, Park J, Crews AL, Slifer SH, Auerbach S, Roy MG, Lin J, Hennessy CE, Schwarz MI, Schwartz DA. A Common MUC5B Promoter Polymorphism and Pulmonary Fibrosis. N Engl J Med 2011; 364: 1503-1512.

42. Wu Y, Byrne EM, Zheng Z, Kemper KE, Yengo L, Mallett AJ, Yang J, Visscher PM, Wray NR. Genome-wide association study of medication-use and associated disease in the UK Biobank. Nat Commun 2019; 10: 1891.

43. UK Biobank GWAS V2 results [Internet]. 2018 [cited 2020 Aug 3].Available from: http://www.nealelab.is/uk-biobank/.

44. Pividori M, Schoettler N, Nicolae DL, Ober C, Im HK. Shared and distinct genetic risk factors for childhood-onset and adult-onset asthma: genome-wide and transcriptome-wide studies. Lancet Respir Med 2019; 7: 509-522.

45. Zhou W, Nielsen JB, Fritsche LG, Dey R, Gabrielsen ME, Wolford BN, LeFaive J, VandeHaar P, Gagliano SA, Gifford A, Bastarache LA, Wei W-Q, Denny JC, Lin M, Hveem K, Kang HM, Abecasis $\mathrm{GR}$, Willer $\mathrm{CJ}$, Lee $\mathrm{S}$. Efficiently controlling for case-control imbalance and sample relatedness in large-scale genetic association studies. Nat Genet 2018; 50: 1335-1341.

46. Ferkingstad E, Oddsson A, Gretarsdottir $S$, Benonisdottir $S$, Thorleifsson $G$, Deaton AM, Jonsson S, Stefansson OA, Norddahl GL, Zink F, Arnadottir GA, Gunnarsson B, Halldorsson GH, Helgadottir A, Jensson BO, Kristjansson RP, Sveinbjornsson G, Sverrisson DA, Masson G, Olafsson I, Eyjolfsson GI, Sigurdardottir O, Holm H, Jonsdottir I, Olafsson S, Steingrimsdottir T, 
medRxiv preprint doi: https://doi.org/10.1101/2022.01.11.22269075; this version posted January 11, 2022. The copyright holder for this preprint (which was not certified by peer review) is the author/funder, who has granted medRxiv a license to display the preprint in perpetuity.

It is made available under a CC-BY 4.0 International license .

Rafnar T, Bjornsson ES, Thorsteinsdottir U, Gudbjartsson DF, et al. Genome-wide association meta-analysis yields 20 loci associated with gallstone disease. Nat Commun 2018; 9: 5101.

47. Onengut-Gumuscu S, Chen W-M, Burren O, Cooper NJ, Quinlan AR, Mychaleckyj JC, Farber E, Bonnie JK, Szpak M, Schofield E, Achuthan P, Guo H, Fortune MD, Stevens H, Walker NM, Ward LD, Kundaje A, Kellis M, Daly MJ, Barrett JC, Cooper JD, Deloukas P, Type 1 Diabetes Genetics Consortium, Todd JA, Wallace C, Concannon P, Rich SS. Fine mapping of type 1 diabetes susceptibility loci and evidence for colocalization of causal variants with lymphoid gene enhancers. Nat. Genet. 2015; 47: 381-386.

48. Liu JZ, van Sommeren S, Huang H, Ng SC, Alberts R, Takahashi A, Ripke S, Lee JC, Jostins L, Shah T, Abedian S, Cheon JH, Cho J, Dayani NE, Franke L, Fuyuno Y, Hart A, Juyal RC, Juyal G, Kim WH, Morris AP, Poustchi H, Newman WG, Midha V, Orchard TR, Vahedi H, Sood A, Sung JY, Malekzadeh R, Westra $\mathrm{H}-\mathrm{J}$, et al. Association analyses identify 38 susceptibility loci for inflammatory bowel disease and highlight shared genetic risk across populations. Nat. Genet. 2015; 47: 979-986.

49. de Lange KM, Moutsianas L, Lee JC, Lamb CA, Luo Y, Kennedy NA, Jostins L, Rice DL, GutierrezAchury J, Ji S-G, Heap G, Nimmo ER, Edwards C, Henderson P, Mowat C, Sanderson J, Satsangi J, Simmons A, Wilson DC, Tremelling M, Hart A, Mathew CG, Newman WG, Parkes M, Lees CW, Uhlig H, Hawkey C, Prescott NJ, Ahmad T, Mansfield JC, et al. Genome-wide association study implicates immune activation of multiple integrin genes in inflammatory bowel disease. Nat. Genet. 2017; 49: 256-261.

50. Franke A, McGovern DPB, Barrett JC, Wang K, Radford-Smith GL, Ahmad T, Lees CW, Balschun $T$, Lee J, Roberts R, Anderson CA, Bis JC, Bumpstead S, Ellinghaus D, Festen EM, Georges M, Green T, Haritunians T, Jostins L, Latiano A, Mathew CG, Montgomery GW, Prescott NJ, Raychaudhuri S, Rotter JI, Schumm P, Sharma Y, Simms LA, Taylor KD, Whiteman D, et al. Genome-wide meta-analysis increases to 71 the number of confirmed Crohn's disease susceptibility loci. Nat Genet 2010; 42: 1118-1125.

51. Jostins L, Ripke S, Weersma RK, Duerr RH, McGovern DP, Hui KY, Lee JC, Schumm LP, Sharma Y, Anderson CA, Essers J, Mitrovic M, Ning K, Cleynen I, Theatre E, Spain SL, Raychaudhuri S, Goyette P, Wei Z, Abraham C, Achkar J-P, Ahmad T, Amininejad L, Ananthakrishnan AN, Andersen V, Andrews JM, Baidoo L, Balschun T, Bampton PA, Bitton A, et al. Host-microbe interactions have shaped the genetic architecture of inflammatory bowel disease. Nature 2012; 491: 119-124.

52. Hazra A, Kraft P, Selhub J, Giovannucci EL, Thomas G, Hoover RN, Chanock SJ, Hunter DJ. Common variants of FUT2 are associated with plasma vitamin B12 levels. Nat. Genet. 2008; 40: 1160-1162.

53. Nongmaithem SS, Joglekar CV, Krishnaveni GV, Sahariah SA, Ahmad M, Ramachandran S, Gandhi M, Chopra H, Pandit A, Potdar RD, H D Fall C, Yajnik CS, Chandak GR. GWAS identifies population-specific new regulatory variants in FUT6 associated with plasma B12 concentrations in Indians. Hum. Mol. Genet. 2017; 26: 2551-2564.

54. Tanaka T, Scheet P, Giusti B, Bandinelli S, Piras MG, Usala G, Lai S, Mulas A, Corsi AM, Vestrini A, Sofi F, Gori AM, Abbate R, Guralnik J, Singleton A, Abecasis GR, Schlessinger D, Uda M, Ferrucci L. Genome-wide association study of vitamin B6, vitamin B12, folate, and homocysteine blood concentrations. Am. J. Hum. Genet. 2009; 84: 477-482. 
medRxiv preprint doi: https://doi.org/10.1101/2022.01.11.22269075; this version posted January 11, 2022. The copyright holder for this preprint (which was not certified by peer review) is the author/funder, who has granted medRxiv a license to display the preprint in perpetuity.

It is made available under a CC-BY 4.0 International license .

55. Hazra A, Kraft P, Lazarus R, Chen C, Chanock SJ, Jacques P, Selhub J, Hunter DJ. Genome-wide significant predictors of metabolites in the one-carbon metabolism pathway. Hum. Mol. Genet. 2009; 18: 4677-4687.

56. Klarin D, Damrauer SM, Cho K, Sun YV, Teslovich TM, Honerlaw J, Gagnon DR, DuVall SL, Li J, Peloso GM, Chaffin M, Small AM, Huang J, Tang H, Lynch JA, Ho Y-L, Liu DJ, Emdin CA, Li AH, Huffman JE, Lee JS, Natarajan P, Chowdhury R, Saleheen D, Vujkovic M, Baras A, Pyarajan S, Di Angelantonio E, Neale BM, Naheed A, et al. Genetics of blood lipids among 300,000 multiethnic participants of the Million Veteran Program. Nat Genet 2018; 50: 1514-1523.

57. Willer CJ, Schmidt EM, Sengupta S, Peloso GM, Gustafsson S, Kanoni S, Ganna A, Chen J, Buchkovich ML, Mora S, Beckmann JS, Bragg-Gresham JL, Chang H-Y, Demirkan A, Den Hertog HM, Do R, Donnelly LA, Ehret GB, Esko T, Feitosa MF, Ferreira T, Fischer K, Fontanillas P, Fraser RM, Freitag DF, Gurdasani D, Heikkilä K, Hyppönen E, Isaacs A, Jackson AU, et al. Discovery and refinement of loci associated with lipid levels. Nat. Genet. 2013; 45: 1274-1283.

58. Teslovich TM, Musunuru K, Smith AV, Edmondson AC, Stylianou IM, Koseki M, Pirruccello JP, Ripatti S, Chasman DI, Willer CJ, Johansen CT, Fouchier SW, Isaacs A, Peloso GM, Barbalic M, Ricketts SL, Bis JC, Aulchenko YS, Thorleifsson G, Feitosa MF, Chambers J, Orho-Melander M, Melander O, Johnson T, Li X, Guo X, Li M, Shin Cho Y, Jin Go M, Jin Kim Y, et al. Biological, clinical and population relevance of 95 loci for blood lipids. Nature 2010; 466: 707-713.

59. Weiss FU, Schurmann C, Guenther A, Ernst F, Teumer A, Mayerle J, Simon P, Völzke H, Radke D, Greinacher A, Kuehn J-P, Zenker M, Völker U, Homuth G, Lerch MM. Fucosyltransferase 2 (FUT2) non-secretor status and blood group B are associated with elevated serum lipase activity in asymptomatic subjects, and an increased risk for chronic pancreatitis: a genetic association study. Gut 2015; 64: 646-656.

60. Hoffmann TJ, Theusch E, Haldar T, Ranatunga DK, Jorgenson E, Medina MW, Kvale MN, Kwok P-Y, Schaefer C, Krauss RM, Iribarren C, Risch N. A large electronic-health-record-based genome-wide study of serum lipids. Nat. Genet. 2018; 50: 401-413.

61. Wu Y, Byrne EM, Zheng Z, Kemper KE, Yengo L, Mallett AJ, Yang J, Visscher PM, Wray NR. Genome-wide association study of medication-use and associated disease in the UK Biobank. Nat Commun 2019; 10: 1891.

62. Liu M, Jiang Y, Wedow R, Li Y, Brazel DM, Chen F, Datta G, Davila-Velderrain J, McGuire D, Tian C, Zhan X, 23andMe Research Team, HUNT All-In Psychiatry, Choquet H, Docherty AR, Faul JD, Foerster JR, Fritsche LG, Gabrielsen ME, Gordon SD, Haessler J, Hottenga J-J, Huang H, Jang S-K, Jansen PR, Ling Y, Mägi R, Matoba N, McMahon G, Mulas A, et al. Association studies of up to 1.2 million individuals yield new insights into the genetic etiology of tobacco and alcohol use. Nat Genet 2019; 51: 237-244.

63. Chambers JC, Zhang W, Sehmi J, Li X, Wass MN, Van der Harst P, Holm H, Sanna S, Kavousi M, Baumeister SE, Coin L, Deng G, Gieger C, Heard-Costa NL, Hottenga J-J, Kühnel B, Kumar V, Lagou V, Liang L, Luan J, Vidal PM, Mateo Leach I, O'Reilly PF, Peden JF, Rahmioglu N, Soininen P, Speliotes EK, Yuan X, Thorleifsson G, Alizadeh BZ, et al. Genome-wide association study identifies loci influencing concentrations of liver enzymes in plasma. Nat. Genet. 2011; 43: 1131-1138.

64. Sanchez-Roige S, Palmer AA, Fontanillas P, Elson SL, 23andMe Research Team, the Substance Use Disorder Working Group of the Psychiatric Genomics Consortium, Adams MJ, Howard DM, 
medRxiv preprint doi: https://doi.org/10.1101/2022.01.11.22269075; this version posted January 11, 2022. The copyright holder for this preprint (which was not certified by peer review) is the author/funder, who has granted medRxiv a license to display the preprint in perpetuity.

It is made available under a CC-BY 4.0 International license .

Edenberg HJ, Davies G, Crist RC, Deary IJ, McIntosh AM, Clarke T-K. Genome-Wide Association Study Meta-Analysis of the Alcohol Use Disorders Identification Test (AUDIT) in Two Population-Based Cohorts. Am J Psychiatry 2019; 176: 107-118.

65. Tian C, Hromatka BS, Kiefer AK, Eriksson N, Noble SM, Tung JY, Hinds DA. Genome-wide association and HLA region fine-mapping studies identify susceptibility loci for multiple common infections. Nat Commun 2017; 8: 599.

66. Kelly RJ, Rouquier S, Giorgi D, Lennon GG, Lowe JB. Sequence and Expression of a Candidate for the Human Secretor Blood Group a(1,2)Fucosyltransferase Gene ( FUT2 ): HOMOZYGOSITY FOR AN ENZYME-INACTIVATING NONSENSE MUTATION COMMONLY CORRELATES WITH THE NONSECRETOR PHENOTYPE. J. Biol. Chem. 1995; 270: 4640-4649.

67. The 1000 Genomes Project Consortium. A global reference for human genetic variation. Nature 2015; 526: 68-74.

68. Ikehara Y, Nishihara S, Yasutomi H, Kitamura T, Matsuo K, Shimizu N, Inada K, Kodera Y, Yamamura Y, Narimatsu H, Hamajima N, Tatematsu M. Polymorphisms of two fucosyltransferase genes (Lewis and Secretor genes) involving type I Lewis antigens are associated with the presence of anti-Helicobacter pylori IgG antibody. Cancer Epidemiol. Biomarkers Prev. 2001; 10: 971-977.

69. Imbert-Marcille B-M, Barbé L, Dupé M, Le Moullac-Vaidye B, Besse B, Peltier C, Ruvoën-Clouet N, Le Pendu J. A FUT2 Gene Common Polymorphism Determines Resistance to Rotavirus A of the P[8] Genotype. The Journal of Infectious Diseases 2014; 209: 1227-1230.

70. Payne DC, Currier RL, Staat MA, Sahni LC, Selvarangan R, Halasa NB, Englund JA, Weinberg GA, Boom JA, Szilagyi PG, Klein EJ, Chappell J, Harrison CJ, Davidson BS, Mijatovic-Rustempasic S, Moffatt MD, McNeal M, Wikswo M, Bowen MD, Morrow AL, Parashar UD. Epidemiologic Association Between FUT2 Secretor Status and Severe Rotavirus Gastroenteritis in Children in the United States. JAMA Pediatr 2015; 169: 1040.

71. Larsson MM, Rydell GEP, Grahn A, Rodríguez-Díaz J, Åkerlind B, Hutson AM, Estes MK, Larson $G$, Svensson L. Antibody Prevalence and Titer to Norovirus (Genogroup II) Correlate with Secretor (FUT2) but Not with ABO Phenotype or Lewis (FUT3) Genotype. J INFECT DIS 2006; 194: 1422-1427.

72. Ruvoën-Clouet N, Belliot G, Le Pendu J. Noroviruses and histo-blood groups: the impact of common host genetic polymorphisms on virus transmission and evolution: Noroviruses and herd innate protection. Rev. Med. Virol. 2013; 23: 355-366.

73. Carlsson B, Kindberg E, Buesa J, Rydell GE, Lidón MF, Montava R, Mallouh RA, Grahn A, Rodríguez-Díaz J, Bellido J, Arnedo A, Larson G, Svensson L. The G428A Nonsense Mutation in FUT2 Provides Strong but Not Absolute Protection against Symptomatic GIl.4 Norovirus Infection. Lopman BA, editor. PLoS ONE 2009; 4: e5593.

74. Barton SJ, Murray R, Lillycrop KA, Inskip HM, Harvey NC, Cooper C, Karnani N, Zolezzi IS, Sprenger N, Godfrey KM, Binia A. FUT2 Genetic Variants and Reported Respiratory and Gastrointestinal Illnesses During Infancy. The Journal of Infectious Diseases 2019; 219: 836843.

75. Innes AL, McGrath KW, Dougherty RH, McCulloch CE, Woodruff PG, Seibold MA, Okamoto KS, Ingmundson KJ, Solon MC, Carrington SD, Fahy JV. The $\mathrm{H}$ antigen at epithelial surfaces is 
medRxiv preprint doi: https://doi.org/10.1101/2022.01.11.22269075; this version posted January 11, 2022. The copyright holder for this preprint (which was not certified by peer review) is the author/funder, who has granted medRxiv a license to display the preprint in perpetuity.

It is made available under a CC-BY 4.0 International license .

associated with susceptibility to asthma exacerbation. Am. J. Respir. Crit. Care Med. 2011; 183: 189-194.

76. Santos-Cortez RLP, Chiong CM, Frank DN, Ryan AF, Giese APJ, Bootpetch Roberts T, Daly KA, Steritz MJ, Szeremeta W, Pedro M, Pine H, Yarza TKL, Scholes MA, Llanes EG d.V., Yousaf S, Friedman N, Tantoco MaLC, Wine TM, Labra PJ, Benoit J, Ruiz AG, de la Cruz RAR, Greenlee C, Yousaf A, Cardwell J, Nonato RMA, Ray D, Ong KMC, So E, Robertson CE, et al. FUT2 Variants Confer Susceptibility to Familial Otitis Media. The American Journal of Human Genetics 2018; 103: 679-690.

77. Taylor SL, Woodman RJ, Chen AC, Burr LD, Gordon DL, McGuckin MA, Wesselingh S, Rogers GB. FUT2 genotype influences lung function, exacerbation frequency and airway microbiota in nonCF bronchiectasis. Thorax 2017; 72: 304-310.

78. Blackwell CC, Jónsdóttir K, Hanson M, Todd WTA, Chaudhuri AKR, Mathew B, Brettle RP, Weir DM. Non-secretion of abo antigens predisposing to infection by Neisseria Meningitidis and Streptococcus Pneumoniae. The Lancet 1986; 328: 284-285.

79. Kachuri L, Francis SS, Morrison M, Boss\&eacute Y, Cavazos TB, Rashkin SR, Ziv E, Witte JS. The landscape of host genetic factors involved in infection to common viruses and SARS-CoV-2 [Internet]. Genetic and Genomic Medicine; 2020 MayAvailable from: http://medrxiv.org/lookup/doi/10.1101/2020.05.01.20088054.

80. Kousathanas A, Pairo-Castineira E, Rawlik K, Stuckey A, Odhams CA, Walker S, Russell CD, Malinauskas T, Millar J, Elliott KS, Griffiths F, Oosthuyzen W, Morrice K, Keating S, Wang B, Rhodes D, Klaric L, Zechner M, Parkinson N, Bretherick AD, Siddiq A, Goddard P, Donovan S, Maslove D, Nichol A, Semple MG, Zainy T, Maleady-Crowe F, Todd L, Salehi S, et al. Whole genome sequencing identifies multiple loci for critical illness caused by COVID-19 [Internet]. Intensive Care and Critical Care Medicine; 2021 SepAvailable from: http://medrxiv.org/lookup/doi/10.1101/2021.09.02.21262965.

81. COVID-19 Host Genetics Initiative. Mapping the human genetic architecture of COVID-19. Nature [Internet] 2021 [cited 2021 Sep 10]; Available from: http://www.nature.com/articles/s41586-021-03767-x.

82. Lindesmith L, Moe C, Marionneau S, Ruvoen N, Jiang X, Lindblad L, Stewart P, LePendu J, Baric R. Human susceptibility and resistance to Norwalk virus infection. Nat. Med. 2003; 9: 548-553.

83. Borén $T$, Falk $P$, Roth KA, Larson $G$, Normark $S$. Attachment of Helicobacter pylori to human gastric epithelium mediated by blood group antigens. Science 1993; 262: 1892-1895.

84. Wacklin P, Mäkivuokko H, Alakulppi N, Nikkilä J, Tenkanen H, Räbinä J, Partanen J, Aranko K, Mättö J. Secretor genotype (FUT2 gene) is strongly associated with the composition of Bifidobacteria in the human intestine. PLOS ONE 2011; 6: e20113.

85. Wacklin P, Tuimala J, Nikkilä J, Sebastian Tims null, Mäkivuokko H, Alakulppi N, Laine P, RajilicStojanovic M, Paulin L, de Vos WM, Mättö J. Faecal microbiota composition in adults is associated with the FUT2 gene determining the secretor status. PLoS ONE 2014; 9: e94863.

86. Rausch P, Rehman A, Künzel S, Häsler R, Ott SJ, Schreiber S, Rosenstiel P, Franke A, Baines JF. Colonic mucosa-associated microbiota is influenced by an interaction of Crohn disease and FUT2 (Secretor) genotype. Proc. Natl. Acad. Sci. U.S.A. 2011; 108: 19030-19035. 
medRxiv preprint doi: https://doi.org/10.1101/2022.01.11.22269075; this version posted January 11, 2022. The copyright holder for this preprint (which was not certified by peer review) is the author/funder, who has granted medRxiv a license to display the preprint in perpetuity.

It is made available under a CC-BY 4.0 International license.

87. Galeev A, Suwandi A, Cepic A, Basu M, Baines JF, Grassl GA. The role of the blood group-related glycosyltransferases FUT2 and B4GALNT2 in susceptibility to infectious disease. International Journal of Medical Microbiology 2021; 311: 151487.

88. Cohen $\mathrm{M}$, Hurtado-Ziola N, Varki A. ABO blood group glycans modulate sialic acid recognition on erythrocytes. Blood 2009; 114: 3668-3676.

89. Walters RW, Pilewski JM, Chiorini JA, Zabner J. Secreted and Transmembrane Mucins Inhibit Gene Transfer with AAV4 More Efficiently than AAV5. J. Biol. Chem. 2002; 277: 23709-23713.

90. Hurd EA, Holmén JM, Hansson GC, Domino SE. Gastrointestinal mucins of Fut2-null mice lack terminal fucosylation without affecting colonization by Candida albicans. Glycobiology 2005; 15: 1002-1007.

91. Magalhães A, Rossez Y, Robbe-Masselot C, Maes E, Gomes J, Shevtsova A, Bugaytsova J, Borén T, Reis CA. Muc5ac gastric mucin glycosylation is shaped by FUT2 activity and functionally impacts Helicobacter pylori binding. Sci Rep 2016; 6: 25575.

92. Radicioni G, Ceppe A, Ford AA, Alexis NE, Barr RG, Bleecker ER, Christenson SA, Cooper CB, Han MK, Hansel NN, Hastie AT, Hoffman EA, Kanner RE, Martinez FJ, Ozkan E, Paine R, Woodruff PG, O'Neal WK, Boucher RC, Kesimer M. Airway mucin MUC5AC and MUC5B concentrations and the initiation and progression of chronic obstructive pulmonary disease: an analysis of the SPIROMICS cohort. Lancet Respir Med 2021; : S2213-2600(21)00079-5.

93. Okeley NM, Alley SC, Anderson ME, Boursalian TE, Burke PJ, Emmerton KM, Jeffrey SC, Klussman K, Law C-L, Sussman D, Toki BE, Westendorf L, Zeng W, Zhang X, Benjamin DR, Senter PD. Development of orally active inhibitors of protein and cellular fucosylation. Proceedings of the National Academy of Sciences 2013; 110: 5404-5409. 